\title{
Piggybacking on the Cholera Toxin: Identification of a Toxoid-binding Protein as an Approach for Targeted Delivery of Proteins to Motor Neurons
}

\author{
Matthew R. Balmforth[a,b], Jessica Haigh ${ }^{[a, b]}$, Christian Tiede ${ }^{[c]}$, Darren C. Tomlinson ${ }^{[c]}$, Jim Deu- \\ chars $^{[b]}$, Michael E. Webb[a], and W. Bruce Turnbull*[a]
}

[a] M. R. Balmforth, J. Haigh, M. E. Webb, W. B. Turnbull School of Chemistry, University of Leeds, Astbury Centre for Structural and Molecular Biology, Leeds, LS2 9JT

[b] M. R. Balmforth, J. Haigh, J. Deuchars, School of Biomedical Sciences, University of Leeds, Faculty of Biological Sciences, Leeds, LS2 9JT

[c] C. Tiede, D. C. Tomlinson, School of Molecular and Cellular Biology, Astbury Centre for Structural and Molecular Biology, University of Leeds, Faculty of Biological Sciences, Leeds, LS2 9JT

KEYWORDS Toxoid $\bullet$ Affimer $\bullet$ Drug delivery $\bullet$ Motor neuron $\bullet$ Cholera toxin

\begin{abstract}
A significant unmet need exists for the delivery of biologic drugs such as polypeptides or nucleic acids, to the central nervous system (CNS) for the treatment and understanding of neurodegenerative diseases. Naturally occurring toxoids have been considered as tools to meet this need. However, due to the complexity of tethering macromolecular drugs to toxins, and the inherent dangers of working with large quantities of recombinant toxin, no such route has been successfully exploited. Developing a method where toxoid and drug can be assembled immediately prior to in vivo administration has the potential to circumvent some of these issues. Using a phage-display screen, we identified two antibody mimetics, Anti-Cholera Toxoid Affimer (ACTA) -A2 and ACTA-C6 that non-covalently associate with the non-binding face of the cholera toxin B-subunit. In a first step toward the development of a non-viral motor neuron drug-delivery vehicle, we show that Affimers can be selectively delivered to motor neurons in vivo.
\end{abstract}

\section{INTRODUCTION}

Research into treatments for degenerative diseases of motor neurons such as amyotrophic lateral sclerosis (ALS), is hampered in part due to the considerable challenges associated with delivery of molecular probes to the central nervous system (CNS). ${ }^{1}$ To complicate matters, recent trends towards the use of biologics as drugs have resulted in a shift in focus from small molecules to macromolecules such as nucleic acids and antibodies. ${ }^{2}$ Typical strategies for cellular penetration and macromolecule delivery have relied in the past on the use of virally derived cell-penetrating peptides (CPPs). ${ }^{3-5}$ But whilst efficient, these vectors lack specificity in both cell targeting and mechanism of cell entry. ${ }^{6}$ Viral delivery methods, such as those based on the Herpes Simplex virus, have been used successfully to transfer therapeutic genes into the CNS for treatment of conditions such as ALS and spinal cord injury. ${ }^{7-9}$ Viral-mediated gene therapy has been limited however by concerns over vector safety and expense of production..$^{10} \mathrm{~A}$ significant need therefore exists for the development of novel technologies to deliver biologics into motor neurons via peripheral administration routes.
$\mathrm{AB}_{5}$ proteins represent a class of bacterial toxins that gain entry to certain cell types through interactions with highly specific surface markers to trigger receptor-mediated endocytosis. ${ }^{11-13}$ One toxoid from the $\mathrm{AB}_{5}$ family, cholera toxin $\mathrm{B}$ subunit (CTB), binds to ganglioside GM1, a membrane-tethered carbohydrate highly expressed at the neuromuscular junction. ${ }^{14,15}$ CTB therefore represents a potential candidate to target motor neurons in vivo for delivery of a cargo.

Indeed, the ability of $\mathrm{B}_{5}$ toxoids to undergo retrograde transport in neurons has led to extensive use of CTBconjugates as neuronal tracers. ${ }^{16-18}$ Tinker et al. previously demonstrated that by mimicking the full-length holotoxin, fluorescent CT chimeras could be produced by replacing the toxic A1 domain with a fluorescent protein. ${ }^{19}$ Chen et al. expanded on this work by expressing fusions with heat-labile enterotoxin IIA, and showing that these could be successfully delivered to the cytosol of neurons in mammalian cell culture. ${ }^{20}$ This approach, however, requires expression of A2 fusions with the desired cargo. Successful formation of $\mathrm{AB}_{5}$ complexes relies on assembly of the $\mathrm{B}_{5}$ pentamer around the A2 $\alpha$-helix, making co-expression a necessity (Figure 1). ${ }^{21}$ For development of a tool to deliver a payload of any kind, co-expression would ideally be avoided, as not all molecules of interest are amenable to forming fusions, 
e.g. nucleic acids and antibodies, and separate expression would prevent extended handling of potentially toxic complexes. Identifying a molecule capable of associating with preassembled CTB pentamer in a non-covalent manner could circumvent these problems, since the cargo of choice could be ligated to the CTB-binding component. Each component could then be produced independently and assembled immediately prior to administration.

(A)

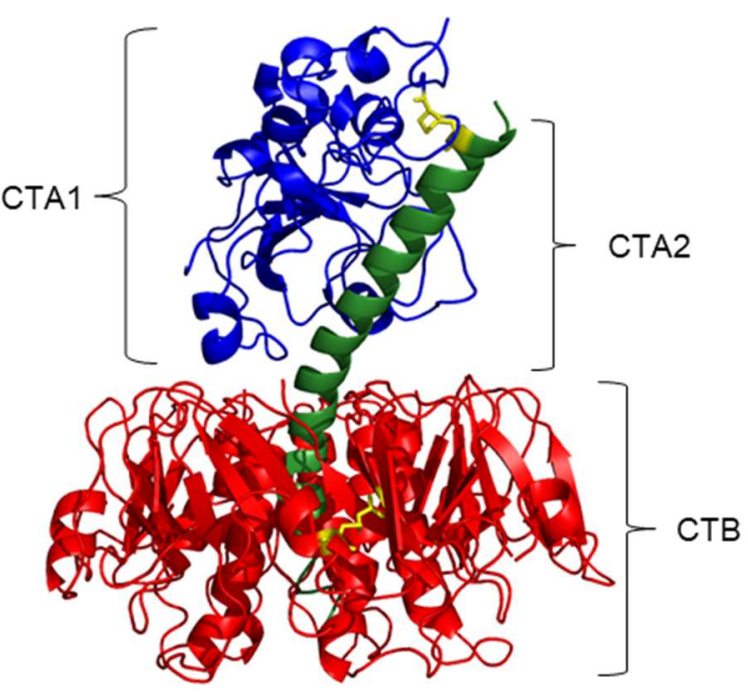

(B)

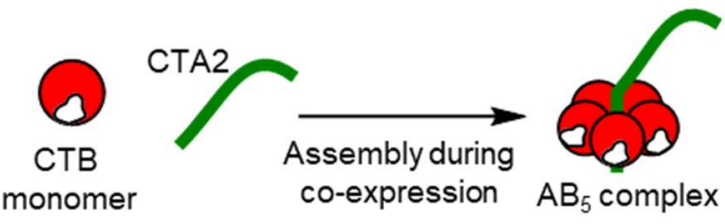

(C)

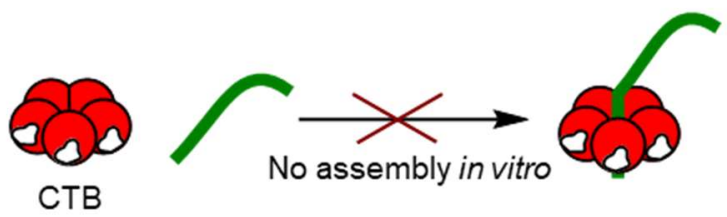

(D)

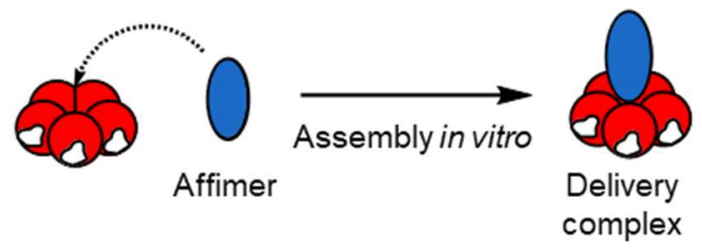

Figure 1. (A) Crystal structure of the $\mathrm{AB}_{5}$ cholera toxin showing the CTA1 subunit (green) associated to CTA2 subunit (green) via a disulfide bond (yellow) which in turn is non-covalently associated with the $\mathrm{B}_{5}$ subunit CTB (red). (B) Co-expression of $\mathrm{A}$ - and $\mathrm{B}$-components leads to assembly of $\mathrm{AB}_{5}$ complex in vivo, while (C) no spontaneous assembly of AB5 complexes occurs upon mixing the B-pentamer with the A2 peptide. (D) The approach described in this paper enabling separate expression of components and simple assembly in vitro to form a delivery complex
Antibody mimetics represent a group of engineered protein scaffolds which reproduce the molecular recognition of antibodies while possessing enhanced properties. These improvements include: minimal size, stability, and ease of expression. ${ }^{22,23}$ Specificity for a particular target is obtained by screening diverse libraries using technologies such as phage, mRNA, or ribosome display that allow the binding capability of the isolated protein to be linked back to its coding sequence. ${ }^{24-26}$ This strategy for high-throughput identification of binding proteins has led to the discovery of novel interactions with affinities comparable to those attained with antibodies. ${ }^{27}$ One recent addition to the family of antibody mimetics is the Affimer, a thermostable scaffold based on a phytocystatin consensus sequence, with two variable nine-residue loops responsible for substrate binding. ${ }^{28,29}$ The availability of this scaffold library led us to postulate that we could identify an Affimer to target the non-binding face of CTB to replicate the formation of an $\mathrm{AB}_{5}$-type complex in vitro, and that this complex would be capable of internalisation into motor neurons and transportation to the cell body in a retrograde fashion to deliver a payload.

Herein we report the first step toward developing this novel technology, in which we use phage display to identify Affimers associating with the non-binding face of CTB. Two binders were identified from an initial screen, termed ACTA-A2 and ACTA-C6, and were shown to form stable complexes with CTB. The technology was then validated in vivo by tongue injection in mice followed by detection in neuronal cells of the brain.

\section{RESULTS AND DISCUSSION}

\section{Identification of CTB-binding Affimers}

CTB for us in phage selections and other downstream processes detailed in this paper was expressed in Vibrio sp. 60 and subsequently purified directly from the culture supernatant, ${ }^{30}$ as the protein is released from the periplasm following accumulation. Typical approaches to identify targetspecific binding proteins by phage display rely on modification of the target to permit immobilisation to a solid support. ${ }^{31-33}$ Recombinant bacteriophage libraries can then be tested against the fixed target in multiple screens to obtain a series of binders. However, modification can be non-specific, resulting in the target being displayed in a variety of orientations. It was critical that Affimer-association did not interfere with the ability of CTB to bind to GM1 as this would impede cellular uptake; thus presentation of CTB in a range of orientations was undesirable. CTB-GM1 complex formation benefits from a particularly high binding affinity (monovalent $K_{\mathrm{d}}=43 \mathrm{nM}$ ) for a protein-carbohydrate interaction, ${ }^{34,35}$ allowing phage display screens to be carried out against unmodified CTB complexed to ganglioside GM1. Adhering ganglioside GM1 to a plate surface ensured that the binding face of CTB was obscured during screening, and that the non-binding face was targeted exclusively. Four consecutive rounds of phage display were conducted in this manner. 
Binding of Affimer-displaying phage particles to CTB was confirmed in the first instance by phage ELISA (Figure S1) which led to the identification of fifteen unique clones. In order to prioritize a subset of binders for full characterisation, a plate-based Affimer-lectin binding assay (ALBA) was established. Affimer coding sequences were subcloned from a phage vector into pET11, to add a C-terminal cysteine and His-tag, with the overexpressed protein biotinylated via maleimide modification. Biotinylated Affimer was then evaluated for its ability to bind to GM1-coated plates in the absence or presence of CTB. The amount of Affimer remaining on the plate surface following extensive wash steps was quantified using a streptavidin-HRP conjugate in the presence of the fluorogenic HRP-substrate Amplex $®$ Red and hydrogen peroxide (Figure 2). Affimers A2, B11, C6, and D3 showed the highest binding relative to the control wells and were thus taken forward for further study. These proteins shall now be referred to as Anti-Cholera Toxoid Affimers (ACTAs).

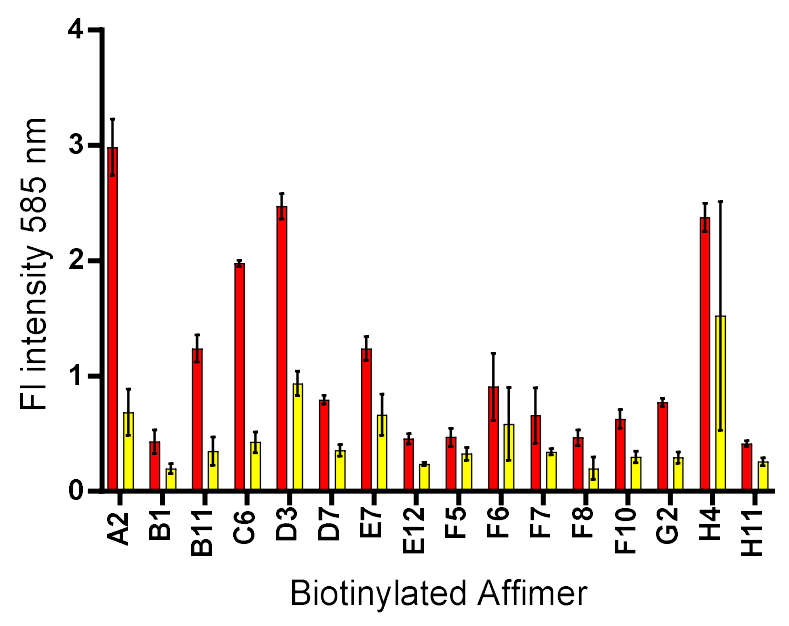

Figure 2. Analysis of CTB-binding Affimers using the Affimerlectin binding assay (ALBA). Each data point represents the signal produced following incubation of a biotinylated Affimer with (red) or without (yellow) CTB, detected using a Streptavidin-HRP conjugate in the presence of Amplex Red and hydrogen peroxide. The fluorescence of the Amplex Red reaction product resorufin was detected at $585 \mathrm{~nm}$ and measured in technical triplicate. Error bars show the standard deviation.

\section{CTB-binding Affimers Demonstrate Selectivity}

In an effort to understand the binding specificity of ACTAs to CTB relative to other similar lectins, the CTB homologue heat-labile enterotoxin B subunit (LTB) was employed. This lectin is $80 \%$ identical to CTB, with many of the differentiating residues exposed on the surface of the protein. ${ }^{36,37} \mathrm{~A}$ similar ALBA was set up, with the five strongest binding proteins to CTB being tested against both CTB and LTB (Figure 3A). ACTA-B11, C6 and D3 appear not to discriminate between the two toxoids. Interestingly, however, ACTA-A2 demonstrated strong selectivity, binding exclusively to CTB. Discrimination between these two highly similar proteins is of particular interest since current commercial antibodies are unable to do so. This assay gave some insight into where ACTA-A2 may be binding, since of the 17 residues that differ between CTB and LTB, only five of these are surface exposed on the non GM1-binding face of CTB. These residues were therefore considered to be the most likely to be forming interactions with the ACTA variable loops (Figure S2).

To tease out the nature of this interaction, five CTB-LTB hybrids were produced, each carrying a single amino acid mutation corresponding to the five residues postulated to mediate ACTA-A2-CTB selectivity (Figure S3). The hybrid proteins were expressed, and the protein-containing media tested directly in the ALBA with ACTA-A2 biotin (Figure 3B).

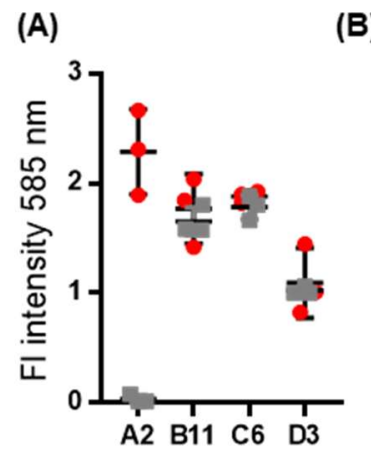

(B)

\section{Biotinylated ACTA}

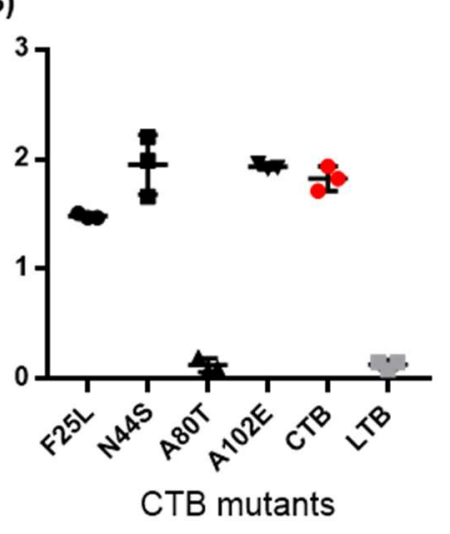

(C)

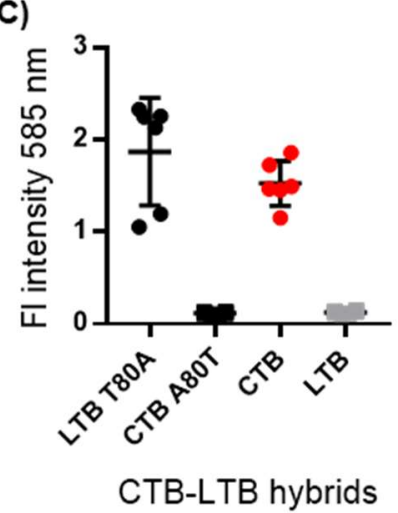

Figure 3. (A) CTB-binding Affimers demonstrate variable selectivity for CTB. Selectivity assays were carried out by incubating GM1 bound CTB (red circles) or GM1 bound LTB (grey squares) with biotinylated ACTA- A2, B11, C6, and D3 in an ALBA assay. (B) ACTA-A2 shows selectivity. Fluorescence detected following testing of ACTA-A2-biotin against a series of five CTB mutants (F25L, N44S, A80T, E83D, A102E, LTB and CTB). (C) A80T facilitates binding of ACTA-A2 to LTB. Fluorescence detected following testing of ACTA-A2-biotin against purified LTB A80T, LTB, or CTB. Signal detected plotted with error bars showing the standard deviation of three technical repeats (A and B) or six technical repeats (C).

Of the hybrids, only one, CTB A80T, no longer bound to ACTA-A2. We therefore generated the corresponding hybrid LTB T80A and tested its interaction with ACTA-A2 biotin in the ALBA (Figure $3 \mathrm{C}$ ). The mutation resulted in a gain in function for LTB, demonstrating that residue A80 in CTB 
bioRxiv preprint doi: https://doi.org/10.1101/2020.05.11.982132; this version posted May 11, 2020. The copyright holder for this preprint (which was not certified by peer review) is the author/funder. All rights reserved. No reuse allowed without permission.

alone is responsible for the observed selectivity of ACTA-A2 for CTB over LTB. A80 lies in a cleft close to the central cavity at the interface of two CTB protomers (Figure 4) which likely provides a binding pocket for one of the variable regions of ACTA-A2. This site could potentially become unavailable when $A 80$ is mutated to a larger amino acid, such as threonine as found in LTB. Since ACTA-B11, C6 and D3 do not discriminate between the two toxoids, it is unlikely that they bind to the same region as ACTA-A2. Instead a conserved region, such as the pentamer pore, is more likely to be critical for binding. Due to their different binding specificities for CTB and LTB, ACTA-A2 and C6 were selected for further biophysical characterisation.

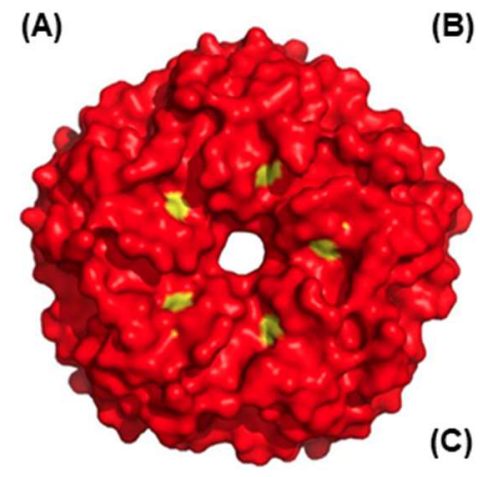

(B)

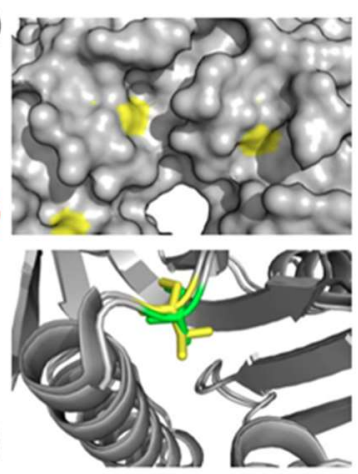

Figure 4. (A) Surface representation of the non-binding face of CTB, with residue A80 coloured in yellow. (B) A close-up image of the hypothesized ACTA-A2 binding groove, showing A80 in yellow. (C) A close-up of an overlay of CTB and LTB with A80 shown in green, and T80 shown in yellow.

Isothermal titration calorimetry (ITC) was applied to measure the binding interaction between each of ACTA-A2 and ACTA-C6 and CTB, with binding constants determined at $37^{\circ} \mathrm{C}$ to simulate temperature in vivo. ITC data is summarized in Table 1. An exothermic heat change was observed for both Affimers, and $K_{\mathrm{d}}$ values of $1.1 \mu \mathrm{M}$ and $97 \mathrm{nM}$ were determined for ACTA-A2 and ACTA-C6, respectively. Importantly this revealed that CTB binds to ACTA-C6 10-fold more tightly than to ACTA-A2. ITC also revealed that each ACTA bound to the CTB pentamer as a 1:1 complex. The 1:1 binding for ACTA-A2 to CTB is consistent with it binding to the central pore of the CTB pentamer with one of its loops projecting into the groove distinguished by $\mathrm{A} 80$. Interestingly, as ACTA-C6 also displays 1:1 binding, it suggests that this Affimer also binds in the central pore, even though it does not distinguish between A80 and T80 in CTB and LTB.
Table 1. Results of ITC experiments

\begin{tabular}{|l|c|c|}
\hline Affimer & ACTA-A2-CTB & ACTA-C6-CTB \\
\hline Temp (K) & 308 & 308 \\
\hline$\Delta \mathbf{H}^{\circ}$ (kcal/mol) & $-23.0 \pm 0.87$ & $-7.33 \pm 0.14$ \\
\hline $\mathbf{\Delta G}^{\circ}$ (kcal/mol) & $-8.40 \pm 1.65$ & $-9.95 \pm 0.19$ \\
\hline $\mathbf{K d}(\mathbf{n M})$ & $1130 \pm 210$ & $97 \pm 30$ \\
\hline $\begin{array}{l}\mathbf{T} \mathbf{\Delta} \mathbf{S}^{\circ} \\
\mathbf{( k c a l} / \mathbf{m o l})\end{array}$ & $-14.64 \pm 2.52$ & $2.62 \pm 0.33$ \\
\hline $\mathbf{n}^{\mathbf{a}}$ & $1.15 \pm 0.03$ & $1.05 \pm 0.01$ \\
\hline $\mathbf{N}^{\mathbf{b}}$ & 3 & 2 \\
\hline
\end{tabular}

a binding stoichiometry; ${ }^{\mathrm{b}}$ number of replicates

\section{Protein delivery in cultured cells}

We next assessed the ability of these novel complexes to be taken up into mammalian cells prior to validation in vivo. As a first proof of concept, ACTA proteins and CTB were labelled with Alexa Fluor 555 and 488 respectively. Sitespecific routes to labelling were carried out to ensure that complex formation would not be impeded by chemical modification. Affimers harbouring a C-terminal cysteine were modified with maleimide fluorophores, while CTB was oxidized with sodium periodate and then modified at its $\mathrm{N}$ termini with aminooxy fluorophores. ${ }^{38}$ ACTA:CTB complexes were produced by combining the toxoid with the Affimers in a 1:1 ratio and subsequently purified by gel filtration (Figure S4). A single peak containing ACTA-555 co-eluted with CTB-488 was collected, and the protein was administered to Vero cells, a cell-line derived from monkey epithelial cells expressing ganglioside GM1. The presence of labelled proteins internalized within the cells was readily detected at concentrations as low as $175 \mathrm{nM}$ and $15 \mathrm{nM}$ for ACTA-A2/CTB and ACTA-C6/CTB respectively (Figure 5 and Figure S5). The difference in affinity between ACTA-A2 and ACTA-C6 for CTB was thus reflected in the minimal concentration threshold required for detection of labelled complex in cell culture.

Analysis of the cell images reveals that CTB and ACTAs clearly co-localize and appear concentrated in discrete puncta in an area directly adjacent to the nucleus that is consistent with the morphology of the Golgi apparatus. CTB is known to enter recycling endosomes, and be transported to the trans-Golgi network from the cell surface, resulting in accumulation of CTB in the Golgi apparatus. ${ }^{39}$ Preliminary analysis of complex localisation therefore appears to agree with previous observations and indicate that ACTA complexes do not alter the endocytic pathway of CTB. 

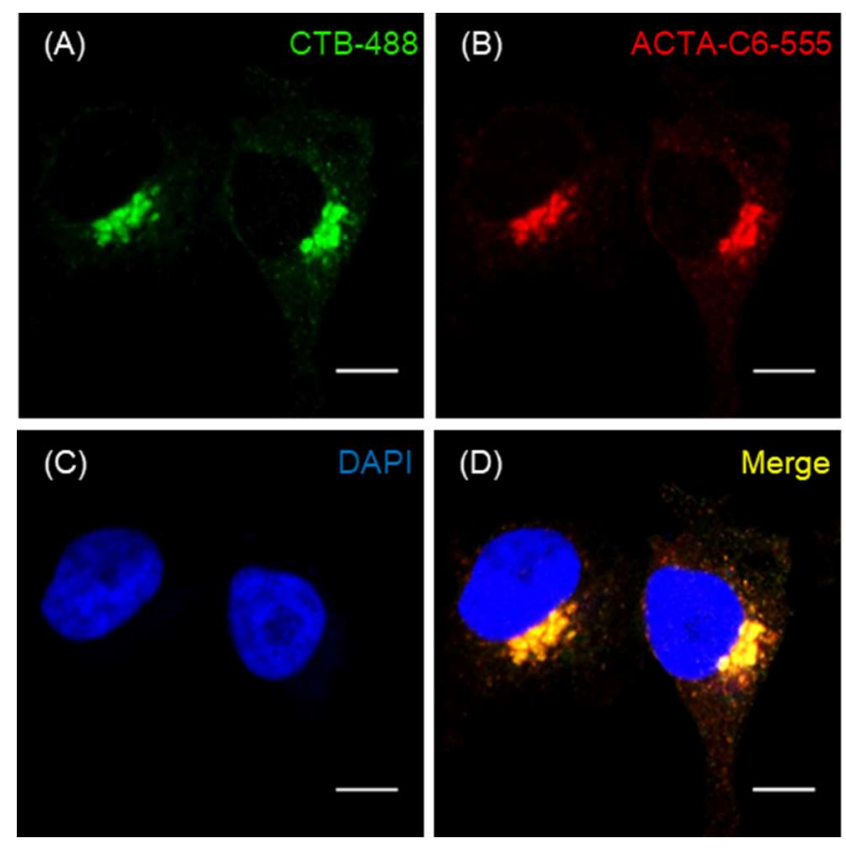

Figure 5. Vero cells treated with CTB-488/ACTA-C6-555 complex to a final concentration of $15 \mathrm{nM}$ and stained with DAPI nuclear stain. Scale bars are $10 \mu \mathrm{m}$. (A) CTB-488 fluorescence, (B) ACTA-C6-555 fluorescence, (C) DAPI nuclear stain blue fluorescence, (D) merged image of 488, 555, $405 \mathrm{~nm}$ wavelengths.

\section{Delivery of Affimers to motor neurons}

Numerous studies report the ability of CTB to be endocytosed into neurons when delivered to the CNS. ${ }^{40,41}$ Neuronal tracing in this capacity has been achieved by intraperitoneal and intravenous injections for broad dispersal of CTB into the neurons of the spinal cord and brain..$^{42} \mathrm{~A}$ more targeted delivery approach that is useful for testing putative reagents, with labelling specifically of the neurons of the hypoglossal nucleus in the brainstem, has been described by intramuscular administration of protein into the tongue, ${ }^{43,44}$ therefore, injections were carried out paralingually. C57BL/6 mice were treated with either $25 \mu \mathrm{g}$ unlabelled CTB complexed with one of the two fluorescently-labelled Affimers (ACTA-A2-555 or ACTA-C6-555), or with one of the three individual components ( $5 \mu \mathrm{g}$ ACTA or $20 \mu \mathrm{g}$ CTB). After 24 hours, cross-sections of the brainstem were prepared and stained with a primary-secondary antibody pair to detect endocytosed CTB. Slides were then viewed by confocal microscopy (Figure 6).

CTB staining and ACTA fluorescence were both observed in the brainstems of mice treated with the complex, but not in mice treated with the fluorescent ACTA alone (Figure S6) demonstrating that ACTA internalisation was dependent on CTB. In a similar manner to earlier experiments carried out in Vero cells, localisation could broadly be assigned to a region peripheral to the motor neuron nucleus. Detection of
ACTA-CTB at the nucleus indicates complete retrograde trafficking of the complex from the neuromuscular junction to the cell body, contained within the brainstem.

The two ACTA-CTB complexes showed different localisation patterns. After 24 hours, ACTA-A2 is observed in small punctate spots throughout the cell, while the fluorescence for ACTA-C6 is peripheral to the nucleus as observed in preliminary cell experiments (see Figure 5/Figure S5). These halos of ACTA-C6-555 fluorescence overlay with the detected CTB, suggesting that the higher affinity ACTA-C6 is still bound to its target after internalisation and trafficking to the cell body. Conversely ACTA-A2-555 fluorescence overlaid poorly with CTB, suggesting that the complex dissociates after internalisation and the stable Affimer is then being sequestered inside endosomes for lysosomal degradation.
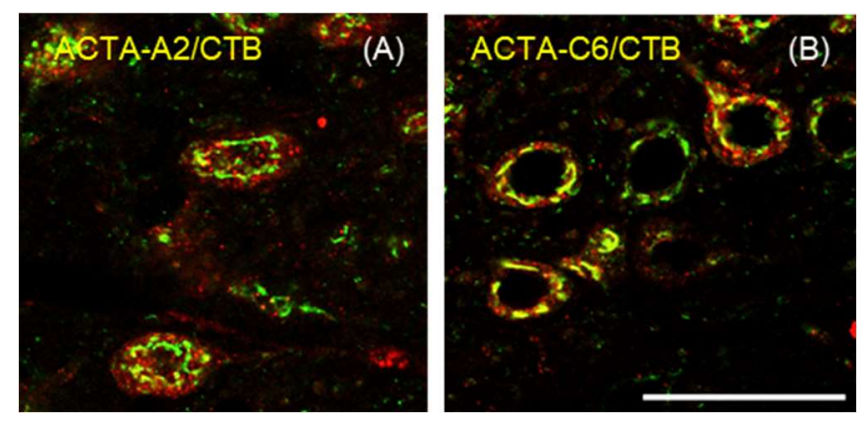

Figure 6. Cells of the hypoglossal nucleus in brainstem crosssections for mice paralingually injected with ACTA-A2555/CTB (left, image (A)) or ACTA-C6-555/CTB (right, image (B)), showing ACTA fluorescence (555 nm, red) overlaid with CTB immunolabelling (488 $\mathrm{nm}$, green). Scale bar $=50 \mu \mathrm{m}$.

A further experiment to establish the longevity of the complex in vivo was carried out by administering the complex paralingually and sacrificing the mice after one week. Few ACTA-A2-555 positive cells were detected, with nearly all remaining fluorescence appearing clustered in punctate spots (Figure 7). ACTA-C6-555, however, was readily detected in the hypoglossal nucleus, with much of ACTA-C6555 fluorescence overlaying with immunostained CTB, indicating a longer-lived half-life for the ACTA-C6/CTB complex. We propose that the lower affinity ACTA-A2 dissociates from CTB rapidly, resulting in a reduced half-life in vivo compared to ACTA-C6, which remains bound for longer, leading to an extended half-life (Figure 8). Of note is that Affimers are derived from phytocystatins, a group of lysosomal protease inhibitors found in plants. Lysosomal degradation of these proteins might therefore be surprising, although the ability of phytocystatins to survive degradation in a mouse lysosome is unknown. It is possible that ACTAA2 persists in the motor neuron, albeit without the fluorescent tag. 
bioRxiv preprint doi: https://doi.org/10.1101/2020.05.11.982132; this version posted May 11, 2020. The copyright holder for this preprint (which was not certified by peer review) is the author/funder. All rights reserved. No reuse allowed without permission.
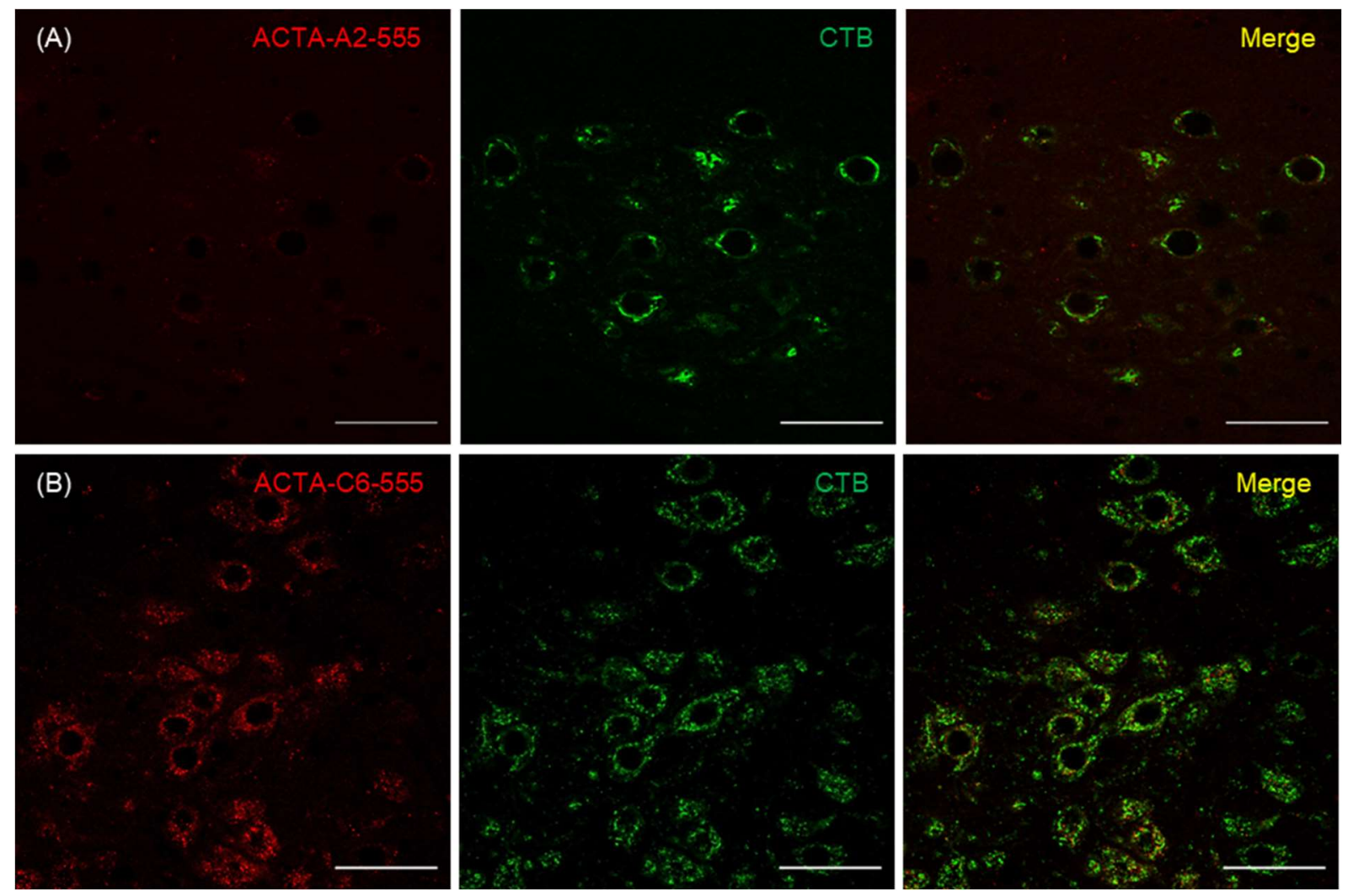

Figure 7. Hypoglossal nucleus in cross-section of brainstems of mice injected paralingually with (A) ACTA-A2-555 + CTB and (B) ACTA-C6-555 + CTB. Mice were sacrificed one week following injections, with CTB detected by immunolabelling. Scale bars $=50 \mu \mathrm{m}$.

(A)

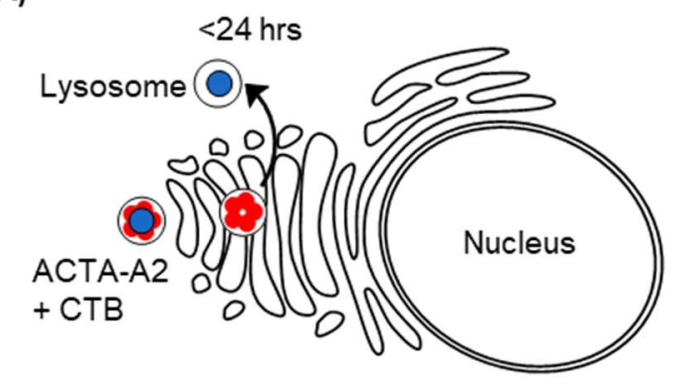

(B)

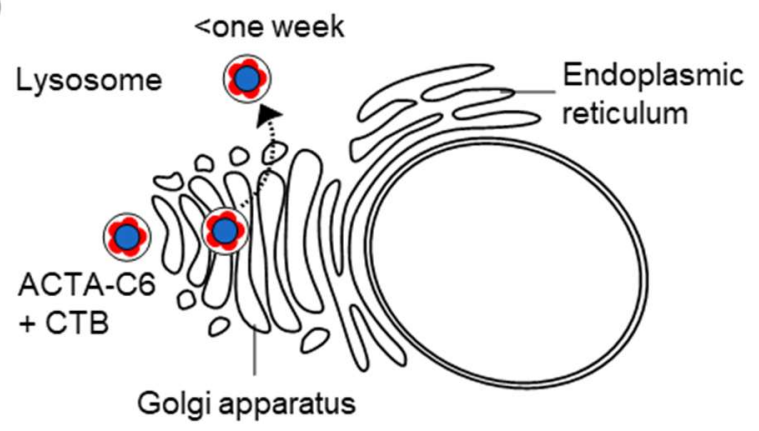

Figure 8. Hypothesis of the fate of the ACTA-CTB complex once internalized into motor neurones. (Top) ACTA-A2-CTB complex is trafficked to the Golgi apparatus in the cell body. Once inside the neuron, ACTA-A2 dissociates from CTB, and is rapidly targeted to lysosomes for degradation. (Bottom) ACTA-C6CTB complex is trafficked to the Golgi apparatus. The complex remains associated and is eventually targeted for lysosomal degradation.

\section{CONCLUSIONS}

CTB has been extensively studied as a tool for neuronal tracing and protein delivery. In this manuscript we expand on the capabilities of CTB by proposing a novel method for carrying macromolecular cargo into the brainstem of a mouse as a first step to developing a motor neuron-selective protein delivery system. By exploiting the GM1-binding properties of the cholera toxin B-subunit, two anti-cholera toxoid Affimers were identified through phage display that target the face distal to the GM1-binding sites of CTB. Using an ELISA-type assay, selectivity for CTB over LTB was demonstrated for ACTA-A2, but not for ACTA-C6. Fluorescently labelled ACTA-CTB assemblies were injected intramuscularly into the tongues of mice and were readily detected in the motor neurons of the hypoglossal nucleus. Intracellular distribution in vivo was noticeably different between ACTAA2/CTB and ACTA-C6/CTB treated mice, with ACTAC6/CTB remaining largely associated, whilst ACTA-A2/CTB appeared to have fully disassembled. After 24 hours ACTAA2 was detectable in discrete vesicles but had significantly reduced after one week. The weaker interaction of the ACTA-A2/CTB complex was hypothesized to be facilitating disassembly in vivo. A lower affinity may be preferable for release of cargo following internalisation and may be necessary to achieve dispersion throughout the neurons of the body. As a proof of concept, we have shown that CTB can be used as a vehicle to deliver a piggybacking cargo into motor neurons. Beyond the use of the CTB:Affimer approach de- 
scribed here, this approach could be applied to any antibody-mimetic and lectin pair to develop a modular protein assembly for intracellular delivery of macromolecular cargo. This strategy therefore has the potential to be adapted to delivery of molecular cargoes to a wide variety of cell types beyond those which interact with CTB.

\section{METHODS}

Affimer Expression See Tiede et al. ${ }^{28}$ for detailed methods. Briefly, an overnight culture of BL21(DE3) cells transformed with pET11-Affimer was used to inoculate $400 \mathrm{~mL}$ LB-ampicillin medium. Cultures were induced with $0.5 \mathrm{mM}$ IPTG at OD 0.6 and incubated at $30^{\circ} \mathrm{C}$ for at least six hours before chemical cell lysis. Clarified supernatant was purified by immobilised nickel affinity chromatography, followed by size exclusion chromatography.

CTB Expression from Vibrio sp. 60 El Tor CTB was expressed from Vibrio sp. 60 transformed with pATA13 as described previously. ${ }^{30}$ In brief, an overnight culture incubated at $30{ }^{\circ} \mathrm{C}$ was used to inoculate $1 \mathrm{~L}$ high-salt LB medium $(2 \% \mathrm{NaCl})$. At OD 0.6 protein expression was induced with IPTG $(0.5 \mathrm{mM})$ and the cells were incubated at $30{ }^{\circ} \mathrm{C}$ for 24 hours. Cells were pelleted by centrifugation and protein was purified directly from the medium by ammonium sulfate precipitation at a final concentration of $57 \% \mathrm{w} / \mathrm{v}$ ammonium sulfate. The saturated solution was then stirred for two hours at room temperature then centrifuged at $18,000 \mathrm{xg}$ for 30 minutes. The supernatant was discarded and the pellet was resuspended in $20 \mathrm{~mL}$ PBS. A second centrifugation was carried out to remove insoluble material. Protein was then purified using a lactose affinity column at $4^{\circ} \mathrm{C}$, and eluted in a lactose-rich buffer $(50 \mathrm{mM}$ phosphate pH 7.4, $300 \mathrm{mM} \mathrm{NaCl}, 300 \mathrm{mM}$ lactose).

Phage Display Phage selections and phage ELISA were carried out as detailed in Tiede et al. ${ }^{28} \mathrm{GM} 1$-coated plates were prepared by adsorption of $100 \mu \mathrm{l} 1.3 \mu \mathrm{M}$ solution of GM1 ganglioside in methanol to Nunc MaxiSorp flat-bottom 96 well plates. The methanol was allowed to evaporate, and the GM1 plates were blocked overnight by incubation at $37^{\circ} \mathrm{C}$ with a casein-based blocking buffer. Plates were washed once with $300 \mu \mathrm{l}$ PBST on a plate washer immediately before use. Three rounds of panning were carried out on GM1coated wells treated with $50 \mu \mathrm{l} 1 \mu \mathrm{M}$ solution of CTB captured for one hour at RT then washed three times with PBS $+0.05 \%$ TWEEN 20 (PBS-T).

Affimer-lectin binding assay Affimers were biotinylated using a 20-fold molar excess of biotin-PEG2-maleimide in $50 \mathrm{mM}$ phosphate $\mathrm{pH} 7.4,300 \mathrm{mM} \mathrm{NaCl}$ supplemented with $1 \mathrm{mM}$ TCEP. Reactions were incubated overnight at RT then dialysed into PBS. Greiner Bio-one high binding black 96 well plates were adsorbed with ganglioside GM1 as described in the previous section. $50 \mu$ lectin (CTB/LTB or similar) $(1 \mu \mathrm{M})$ was transferred to the appropriate wells, and left to bind for one hour at RT. Plates were washed once with PBS-T, and $100 \mu$ l biotinylated Affimer ( $250 \mathrm{nM}$ ) was added to each well. Plates were washed once after Affimer binding at RT for one hour. $50 \mu$ streptavidin-HRP complex (Ultra Streptavidin-HRP, Life Technologies) diluted at 1:1000 in PBS was added to the wells of the plate. The one hour incubation was repeated and the plate was washed six times. A solution of Amplex Red and hydrogen peroxide in PBS, both at a final concentration of $5 \mu \mathrm{M}$, was made up and $50 \mu \mathrm{l}$ of this substrate was added per well. Plates were loaded into a plate reader for fluorescence detection at 585 nm.

Labelling Affimers with Alexa Fluor 555 C2 maleimide $400 \mu \mathrm{l}$ Affimer C-term Cys $(150 \mu \mathrm{M})$ in $50 \mathrm{mM}$ phosphate, $150 \mathrm{mM} \mathrm{NaCl}, 0.5 \mathrm{mM}$ TCEP, pH 7.2 was combined with 0.94 mg Alexa Fluor 555 C2 maleimide (equal to five molar equivalents). Samples were incubated at room temperature for four hours in foil, before purification using a PD-10 desalting column, concentration to $250 \mu \mathrm{l}$, and purification by gel filtration using an analytical Superdex 75 increase column.

Labelling CTB with aminooxy Alexa Fluor 488 CTB was labelled with aminooxy Alexa Fluor 488 by oxidising the Nterminal threonine, and combining the subsequent oxidised CTB with two molar equivalents of the lyophilised fluorophore. CTB (500 $\mu \mathrm{M}$ [protomer concentration], in PBS), Lmethionine (10 equivalents), and $\mathrm{NaIO}_{4}$ (5 equivalents) in phosphate buffer, were incubated together at room temperature out of light for 45 minutes, before buffer exchanging into PBS (pH 6.8) using a PD10 desalting column. The eluate was concentrated to $0.5 \mathrm{~mL}(\sim 500 \mu \mathrm{M})$, and added to $0.4 \mathrm{mg}$ lyophilised fluorophore ( 2 molar equivalents) and $4.5 \mu \mathrm{l}$ aniline (neat). To reduce the number of fluorophores per pentamer, the amount of fluorophore can be reduced to 0.4 molar equivalents. After a 20 hour incubation, the protein was purified using a G25 desalting column, concentrated to $0.5 \mathrm{~mL}$, and purified by gel filtration.

Isothermal Titration Calorimetry All ITC experiments were performed using a MicroCal ITC 200 . An initial sacrificial titration of $0.5 \mu \mathrm{l}$ was required, before $19 \times 2 \mu$ titrations were carried out, each spaced out over 4 seconds, with a 120 second delay in between each injection. Experiments were initially carried out at $100 \mu \mathrm{M} \mathrm{CTB}$, titrated into $10 \mu \mathrm{M}$ Affimer. These concentrations were then varied, if necessary, to obtain a sigmoidal shape of curve. For each set of concentrations, a CTB titration into buffer was carried out to obtain a measure of the heat of dilution of CTB into buffer. These data could then be subtracted from the data obtained from ligand into receptor titrations to bring the baseline closer to zero, thereby facilitating curve fitting. Data were analysed and fitted with a 'one site bind' model using Origin Microcal software. 
bioRxiv preprint doi: https://doi.org/10.1101/2020.05.11.982132; this version posted May 11, 2020. The copyright holder for this preprint (which was not certified by peer review) is the author/funder. All rights reserved. No reuse allowed without permission.

Cell Preparation and Analysis Seeded cells $\left(1.2 \times 10^{5}\right.$ cells per well) in 12-well plates to be treated with protein were washed, by replacing the Cell Culture Media with $1 \mathrm{~mL}$ fresh media. Protein solution was then added directly to the media, and the cells were incubated for $4-6$ hours at $37^{\circ} \mathrm{C}, 5 \%$ $\mathrm{CO}_{2}$ prior to cell fixation. Growth medium was removed, and the cells were washed three times with PBS. $0.5 \mathrm{~mL}$ Cell Cleansing Buffer was added, and incubated at $4{ }^{\circ} \mathrm{C}$ for 6 minutes. The cleansed cells were then washed an additional three times, before addition of $4 \% \mathrm{v} / \mathrm{v}$ paraformaldehyde (PFA) in PBS for 30 minutes at room temperature in a fume hood. The PFA was removed, and the cells were washed three times with PBS. Cells were then permeabilised with $0.1 \%$ Triton X-100 in PBS for one hour at room temperature in preparation for immunohistochemistry.

Animals All animal experimentation was carried out under a Home Office License, and in accordance with the regulations of the UK Animals, Scientific Procedures, Act 1986. Experiments were performed on young male and female C75BL/6 adult mice, bred in house.

The tongue was targeted for intramuscular injections of protein and protein complexes, since it provided a route to deliver material into the motor neurones of the brainstem. CTB-ACTA complexes were prepared at $200 \mu \mathrm{M}$ then injected via paralingual administration of $2 \mu \mathrm{l}$ of protein material. Mice were sacrificed after $24-96$ hours. Brainstems were removed, fixed in $4 \%$ PFA for 24 hours at $4^{\circ} \mathrm{C}$, then prepared for sectioning. All sections were taken transversely on a VT1000S vibrating microtome at $50 \mu \mathrm{m}$ thickness. The sectioned slices were collected and transferred into PBS in a 24-well plate. Tissue sections and cultured cells were permeabilised and treated with rabbit anti-CTB diluted 1:1000 in PBS and incubated overnight at $4{ }^{\circ} \mathrm{C}$. A 1:1000 dilution of a fluorescent secondary antibody in PBS was prepared and added to the sample for one hour, then removed and washed three times with PBS. The sample was then air-dried onto a glass microscope slide before addition of $10 \mu \mathrm{l}$ of Vectashield Mounting Medium and protection of the sample with a cover slip ready for visualisation.

Confocal Microscopy For confocal analysis of samples, an Axio Imager Z2 LSM880 upright confocal microscope (Zeiss) equipped with a $405 \mathrm{~nm}$ diode laser, Argon 458/488/514 nm, DPSS $561 \mathrm{~nm}$ and HeNe $633 \mathrm{~nm}$ lasers and a GaAsP detector. Images were captured using the Zeiss LSM Image browser software, and processed using Zen lite 2.3 software. For wide-field analysis of samples, a Nikon Eclipse E600 microscope equipped with epifluoresence and Q-Imaging Micropublishing 5.0 camera was used. Images were captured using AcQuis image capture software.

\section{ASSOCIATED CONTENT}

Detailed experimental procedures and supplementary data presented in Supporting Information.

\section{AUTHOR INFORMATION}

\author{
Corresponding Author \\ * Professor Bruce Turnbull \\ w.b.turnbull@leeds.ac.uk
}

\section{Author Contributions}

All authors have given approval to the final version of the manuscript.

\section{Funding Sources}

Funding to Matthew R. Balmforth - Wellcome Trust (102576/Z/13/Z); Funding to Jessica Haigh - Biotechnology and Biological Sciences Research Council (BB/J014443/1); Equipment facility funding - Wellcome (094232/Z/10/Z and WT104918MA)

\section{ACKNOWLEDGMENT}

This work was supported by the Wellcome Trust and the Biotechnology and Biological Sciences Research Council - see funding sources.

\section{ABBREVIATIONS}

ACTA, anti-cholera toxoid Affimer; ALS, amyotrophic lateral sclerosis; CNS, central nervous system; CPP, cell-penetrating petides; CTB, cholera toxin B-subunit; HRP, horse-radish peroxidase; ELISA, enzyme-linked immunosorbent assay; ALBA, Affimer-lectin binding assay; LTB, heat-labile enterotoxin B subunit; ITC, isothermal titration calorimetry.

\section{REFERENCES}

(1) Barchet, T. M.; Amiji, M. M. Challenges and Opportunities in CNS Delivery of Therapeutics for Neurodegenerative Diseases. Expert Opin. Drug Deliv. 2009, 6 (3), 211-225. https://doi.org/10.1517/17425240902758188.

(2) Leader, B.; Baca, Q. J.; Golan, D. E. Protein Therapeutics: A Summary and Pharmacological Classification. Nat. Rev. Drug Discov. 2008, 7 (1), 21-39. https://doi.org/10.1038/nrd2399.

(3) Munyendo, W. L.; Lv, H.; Benza-Ingoula, H.; Baraza, L. D.; Zhou, J. Cell Penetrating Peptides in the Delivery of Biopharmaceuticals. Biomolecules 2012, 2 (2), 187-202. https://doi.org/10.3390/biom2020187.

Boisguérin, P.; Deshayes, S.; Gait, M. J.; O’Donovan, L.; Godfrey, C.; Betts, C. A.; Wood, M. J. A.; Lebleu, B. Delivery of Therapeutic Oligonucleotides with Cell Penetrating Peptides. Adv. Drug Deliv. Rev. 2015. https://doi.org/10.1016/j.addr.2015.02.008.

(5) Herce, H. D.; Schumacher, D.; Schneider, A. F. L.; Ludwig, A. K.; Mann, F. A.; Fillies, M.; Kasper, M. A.; Reinke, S.; Krause, E.; Leonhardt, H.; et al. Cell-Permeable Nanobodies for Targeted Immunolabelling and Antigen Manipulation in Living Cells. Nat. Chem. 2017, 9 (8), 762-771. https://doi.org/10.1038/nchem.2811.

(6) Lalatsa, A.; Schatzlein, A. G.; Uchegbu, I. F. Strategies to Deliver Peptide Drugs to the Brain. Mol. Pharm. 2014, 11 (4), 1081-1093. https://doi.org/10.1021/mp400680d. H. Retrograde Viral Delivery of IGF-1 Prolongs Survival in a Mouse ALS Model. Science 2003, 301 (5634), 839-842. https://doi.org/10.1126/science.1086137. 
bioRxiv preprint doi: https://doi.org/10.1101/2020.05.11.982132; this version posted May 11, 2020. The copyright holder for this preprint (which was not certified by peer review) is the author/funder. All rights reserved. No reuse allowed without permission.

(8) Azzouz, M.; Ralph, G. S.; Storkebaum, E.; Walmsley, L. E.; Mitrophanous, K. A.; Kingsman, S. M.; Carmeliet, P.; Mazarakis, N. D. VEGF Delivery with Retrogradely Transported Lentivector Prolongs Survival in a Mouse ALS Model. Nature 2004, 429 (6990), 413-417. https://doi.org/10.1038/nature02544.

(9) Foust, K. D.; Wang, X.; McGovern, V. L.; Braun, L.; Bevan, A. K.; Haidet, A. M.; Le, T. T.; Morales, P. R.; Rich, M. M.; Burghes, A. H. M.; et al. Rescue of the Spinal Muscular Atrophy Phenotype in a Mouse Model by Early Postnatal Delivery of SMN. Nat. Biotechnol. 2010, 28 (3), 271-274. https://doi.org/10.1038/nbt.1610.

(10) Schmidt-Wolf, G. D.; Schmidt-Wolf, I. G. H. Non-Viral and Hybrid Vectors in Human Gene Therapy: An Update. Trends Mol. Med. 2003, 9 (2), 67-72. https://doi.org/10.1016/S1471-4914(03)00005-4.

(11) Merritt, E. A.; Hol, W. G. AB5 Toxins. Curr. Opin. Struct. Biol. 1995, 5 (2), 165-171.

(12) Lencer, W. I.; Tsai, B. The Intracellular Voyage of Cholera Toxin: Going Retro. Trends in Biochemical Sciences. Elsevier Current Trends December 2003, pp 639-645. https://doi.org/10.1016/j.tibs.2003.10.002.

(13) Beddoe, T.; Paton, A. W.; Le Nours, J.; Rossjohn, J.; Paton, J. C. Structure, Biological Functions and Applications of the AB5 Toxins. Trends Biochem. Sci. 2010, 35 (7), 411-418. https://doi.org/10.1016/j.tibs.2010.02.003.

(14) Ledeen, R. W.; Wu, G.; Lu, Z. H.; Kozireski-Chuback, D.; Fang, Y. The Role of GM1 and Other Gangliosides in Neuronal Differentiation. Overview and New Finding. Ann. N. Y. Acad. Sci. 1998, 845, 161-175.

(15) Yuyama, K.; Yanagisawa, K. Sphingomyelin Accumulation Provides a Favorable Milieu for GM1 Ganglioside-Induced Assembly of Amyloid $\beta$-Protein. Neurosci. Lett. 2010, 481 (3), $168-172$. https://doi.org/10.1016/j.neulet.2010.06.080.

(16) Mcllhinney, R. a; Bacon, S. J.; Smith, a D. A Simple and Rapid Method for the Production of Cholera B-Chain Coupled to Horseradish Peroxidase for Neuronal Tracing. J. Neurosci. Methods 1988, 22 (3), 189-194. https://doi.org/10.1016/0165-0270(88)90039-8.

(17) Zhou, N.; Hao, Z.; Zhao, X.; Maharjan, S.; Zhu, S.; Song, Y.; Yang, B.; Lu, L. A Novel Fluorescent Retrograde Neural Tracer: Cholera Toxin B Conjugated Carbon Dots. Nanoscale 2015, 7 (38), 15635-15642. https://doi.org/10.1039/C5NR04361A.

(18) Yao, F.; Zhang, E.; Gao, Z.; Ji, H.; Marmouri, M.; Xia, X. Did You Choose Appropriate Tracer for Retrograde Tracing of Retinal Ganglion Cells. the Differences between Cholera Toxin Subunit B and Fluorogold. PLoS One 2018, 13 (10). https://doi.org/10.1371/journal.pone.0205133.

(19) Tinker, J. K.; Erbe, J. L.; Holmes, R. K. Characterization of Fluorescent Chimeras of Cholera Toxin and Escherichia Coli Heat-Labile Enterotoxins Produced by Use of the Twin Arginine Translocation System. Infect. Immun. 2005, 73 (6), 3627-3635. https://doi.org/10.1128/IAI.73.6.3627-3635.2005.

(20) Chen, C.; Przedpelski, A.; Tepp, W. H.; Pellett, S.; Johnson, E. A.; Barbieri, J. T. Heat-Labile Enterotoxin Iia, a Platform to Deliver Heterologous Proteins into Neurons. MBio 2015, 6 (4), 4-11. https://doi.org/10.1128/mBio.0073415.

(21) Hatic, S. O.; McCann, J. a; Picking, W. D. In vitro Assembly of Novel Cholera Toxin-like Complexes. Anal. Biochem.
2001

292

(2),

171-177. https://doi.org/10.1006/abio.2001.5084.

(22) Hey, T.; Fiedler, E.; Rudolph, R.; Fiedler, M. Artificial, NonAntibody Binding Proteins for Pharmaceutical and Industrial Applications. Trends Biotechnol. 2005, 23 (10), 514-522. https://doi.org/10.1016/j.tibtech.2005.07.007.

(23) Skerra, A. Alternative Non-Antibody Scaffolds for Molecular Recognition. Curr. Opin. Biotechnol. 2007, 18 (4), 295-304. https://doi.org/10.1016/j.copbio.2007.04.010.

(24) Azzazy, H. M. E.; Highsmith, W. E. Phage Display Technology: Clinical Applications and Recent Innovations. Clin. Biochem. 2002, 35 (6), 425-445. https://doi.org/10.1016/S0009-9120(02)00343-0.

(25) Schaffitzel, C.; Hanes, J.; Jermutus, L.; Plückthun, A. Ribosome Display: An in vitro Method for Selection and Evolution of Antibodies from Libraries. J. Immunol. Methods 1999, 231 (1), 119-135. https://doi.org/10.1016/S0022-1759(99)00149-0.

(26) Wilson, D. S.; Keefe, A. D.; Szostak, J. W. The Use of MRNA Display to Select High-Affinity Protein-Binding Peptides. Proc. Natl. Acad. Sci. 2001, 98 (7), 3750-3755. https://doi.org/10.1073/pnas.061028198.

(27) Schilling, J.; Schöppe, J.; Plückthun, A. From DARPins to LoopDARPins: Novel LoopDARPin Design Allows the Selection of Low Picomolar Binders in a Single Round of Ribosome Display. J. Mol. Biol. 2014, 426 (3), 691-721. https://doi.org/10.1016/j.jmb.2013.10.026.

(28) Tiede, C.; Tang, A. A. S.; Deacon, S. E.; Mandal, U.; Nettleship, J. E.; Owen, R. L.; George, S. E.; Harrison, D. J.; Owens, R. J.; Tomlinson, D. C.; et al. Adhiron: A Stable and Versatile Peptide Display Scaffold for Molecular Recognition Applications. Protein Eng. Des. Sel. 2014, 27 (5), 145-155. https://doi.org/10.1093/protein/gzu007.

(29) Tiede, C.; Bedford, R.; Heseltine, S. J.; Smith, G.; Wijetunga, I.; Ross, R.; AlQallaf, D.; Roberts, A. P. E.; Balls, A.; Curd, A.; et al. Affimer Proteins Are Versatile and Renewable Affinity Reagents. Elife 2017, 6. https://doi.org/10.7554/eLife.24903.

(30) Aman, A. T.; Fraser, S.; Merritt, E. A.; Rodigherio, C.; Kenny, M.; Ahn, M.; Hol, W. G.; Williams, N. A.; Lencer, W. I.; Hirst, T. R. A Mutant Cholera Toxin B Subunit That Binds GM1Ganglioside but Lacks Immunomodulatory or Toxic Activity. Proc. Natl. Acad. Sci. U. S. A. 2001, 98 (15), 85368541. https://doi.org/10.1073/pnas.161273098.

(31) Clackson, T.; Lowman, H. B. Phage Display: A Practical Approach; OUP Oxford, 2004.

(32) Koide, A.; Wojcik, J.; Gilbreth, R. N.; Reichel, A.; Piehler, J.; Koide, S. Accelerating Phage-Display Library Selection by Reversible and Site-Specific Biotinylation. Protein Eng. Des. Sel. 2009, 22 (11), 685-690. https://doi.org/10.1093/protein/gzp053.

(33) Tang, A. A. S.; Tiede, C.; Hughes, D. J.; McPherson, M.; Tomlinson, D. C. Isolation of Isoform-Specific Binding Proteins (Affimers) by Phage Display Using Negative Selection. Sci. Signal. 2017, 10 (505). https://doi.org/10.1126/scisignal.aan0868.

(34) Merritt, E. A.; Sarfaty, S.; Akker, F. Van Den; L'Hoir, C.; Martial, J. A.; Hol, W. G. J. Crystal Structure of Cholera Toxin B-pentamer Bound to Receptor GM1 Pentasaccharide. Protein Sci. 1994, 3 (2), 166-175. https://doi.org/10.1002/pro.5560030202.

(35) Turnbull, W. B.; Precious, B. L.; Homans, S. W. Dissecting 
bioRxiv preprint doi: https://doi.org/10.1101/2020.05.11.982132; this version posted May 11, 2020. The copyright holder for this preprint (which was not certified by peer review) is the author/funder. All rights reserved. No reuse allowed without permission.

the Cholera Toxin-Ganglioside GM1 Interaction by Isothermal Titration Calorimetry. J. Am. Chem. Soc. 2004, $126 \quad$ (4), 1047-1054. https://doi.org/10.1021/ja0378207.

(36) Sixma, T. K.; Kalk, K. H.; van Zanten, B. A. M.; Dauter, Z.; Kingma, J.; Witholt, B.; Hol, W. G. J. Refined Structure of Escherichia Coli Heat-Labile Enterotoxin, a Close Relative of Cholera Toxin. J. Mol. Biol. 1993, 230 (3), 890-918. https://doi.org/10.1006/jmbi.1993.1209.

(37) Sixma, T. K.; Pronk, S. E.; Kalk, K. H.; Wartna, E. S.; Van Zanten, B. A. M.; Witholt, B.; Hoi, W. G. J. Crystal Structure of a Cholera Toxin-Related Heat-Labile Enterotoxin from E. Coli. Nature 1991, 351 (6325), 371-377. https://doi.org/10.1038/351371a0.

(38) Chen, J.; Zeng, W.; Offord, R.; Rose, K. A Novel Method for the Rational Construction of Well-Defined Immunogens: The Use of Oximation to Conjugate Cholera Toxin B Subunit to a Peptide-Polyoxime Complex. Bioconjug. Chem. 2003, 14 (3), 614-618. https://doi.org/10.1021/bc025651u.

(39) Machin, D.; Williamson, D.; Fisher, P.; miller, victoria; Wildsmith, G.; Ross, J.; Wasson, C.; MacDonald, A.; Andrews, B. I.; Ungar, D.; et al. Sortase-Modified Cholera Toxoids Show Specific Golgi Localization. 2019. https://doi.org/10.26434/CHEMRXIV.9125201.V1.

(40) Luppi, P. H.; Fort, P.; Jouvet, M. Iontophoretic Application of Unconjugated Cholera Toxin B Subunit (CTb) Combined with Immunohistochemistry of Neurochemical Substances: A Method for Transmitter Identification of Retrogradely Labeled Neurons. Brain Res. 1990, 534 (12), 209-224. https://doi.org/10.1016/00068993(90)90131-T.

(41) Conte, W. L.; Kamishina, H.; Reep, R. L. The Efficacy of the Fluorescent Conjugates of Cholera Toxin Subunit B for Multiple Retrograde Tract Tracing in the Central Nervous System. Brain Struct. Funct. 2009, 213 (4-5), 367-373. https://doi.org/10.1007/s00429-009-0212-x.

(42) Havton, L. A.; Broman, J. Systemic Administration of Cholera Toxin B Subunit Conjugated to Horseradish Peroxidase in the Adult Rat Labels Preganglionic Autonomic Neurons, Motoneurons, and Select Primary Afferents for Light and Electron Microscopic Studies. J. Neurosci. Methods 2005, 149 (2), 101-109. https://doi.org/10.1016/j.jneumeth.2005.03.014.

(43) Lind, L. A.; Murphy, E. R.; Lever, T. E.; Nichols, N. L. Hypoglossal Motor Neuron Death via Intralingual CTBSaporin (CTB-SAP) Injections Mimic Aspects of Amyotrophic Lateral Sclerosis (ALS) Related to Dysphagia HHS Public Access. Neuroscience 2018, 390, 303-316. https://doi.org/10.1016/j.neuroscience.2018.08.026.

(44) Schwarz, E. C.; Thompson, J. M.; Ae, N. P. C.; Behan, M. The Effects of Aging on Hypoglossal Motoneurons in Rats. https://doi.org/10.1007/s00455-008-9169-9. 